\title{
Relationship Among Concentrations of Sphaerotheca macularis Conidia in the Air, Environmental Conditions, and the Incidence of Powdery Mildew in Strawberry
}

\author{
C. Blanco, B. de los Santos, C. Barrau, F. T. Arroyo, M. Porras, and F. Romero, C.I.F.A. Las Torres -Tomejil, \\ Apdo. de Correos Oficial, Alcalá del Río. 41200 Sevilla, Spain
}

\begin{abstract}
Blanco, C., de los Santos, B., Barrau, C., Arroyo, F. T., Porras, M., and Romero, F. 2004. Relationship among concentrations of Sphaerotheca macularis conidia in the air, environmental conditions, and the incidence of powdery mildew in strawberry. Plant Dis. 88:878-881.

Atmospheric concentrations of Sphaerotheca macularis conidia were monitored for 2 years on a strawberry crop in Huelva (southwestern Spain). The presence of airborne conidia was determined to assess the role of weather conditions on conidial release. The relationship between airborne conidia and incidence of powdery mildew on fruit was also studied. Concentrations of conidia were estimated with a Burkard volumetric spore sampler. The presence of conidia was related to temperature, relative humidity, and rainfall, with a positive correlation for the first factor and a negative correlation with the other two. The presence of conidia in the air was positively correlated with disease incidence. A diurnal pattern of conidia release was observed.
\end{abstract}

Additional keywords: aerobiology, epidemiology

Strawberry (Fragaria $\times$ ananassa Duch.) is one of the most important crops in Huelva (southwestern Spain), with more than 7,000 ha cultivated in 2001 (1). Powdery mildew is caused by the obligate parasite Sphaerotheca macularis (Wall. ex Fries) Jacz f. sp. fragariae (Peries). It is one of the most common diseases on the aerial parts of the plant and has been reported worldwide (18). In southwestern Spain, it was first confirmed in 2001 (5).

Symptoms of powdery mildew appear on leaves, flowers, and fruits. Leaves curl upward with spoon-like shapes and white mycelium on the surface (21). Flowers and peduncles can be covered by white mycelium (18). Infected fruit become hard, covered by white mycelium, and unmarketable $(10,11)$.

Control of powdery mildew relies on the application of protectant and systemic fungicides, beginning early in the flowering period. The disease can be controlled by foliar applications of sulfur (16). Aerobiological studies could lead to a better understanding of the biology and epidemiology of $S$. macularis and contribute to the development of a disease management program to avoid unnecessary fungicide applications without increased risk of disease.

The aim of this work was to determine the relationship of environmental condi-

Corresponding author: B. de los Santos

E-mail: bertas.garcia.ext@juntadeandalucia.es

Accepted for publication 12 April 2004.

Publication no. D-2004-0607-01R

(C) 2004 The American Phytopathological Society tions with the presence of conidia of $S$. macularis in the air during two strawberry crop seasons (2000-2001 and 2001-2002). The relationship between aerial conidia and incidence of powdery mildew on ripe fruit was also investigated.

\section{MATERIALS AND METHODS}

Sampling was carried out in an experimental strawberry farm located near Moguer (Huelva District, southwestern Spain) for two growing seasons from October to May in 2001 and 2002 in the same plot. The soil (90\% sand, $2.8 \%$ slime, and $7.2 \%$ clay) had never been previously fumigated, and strawberry had not been grown there for 10 years prior to the start of this work. The plot consisted of treated-plant and untreated-plant subplots of two cultivars (Andana and Camarosa) in a randomized complete block with four replicates. Each subplot was $1.5 \times 12.5 \mathrm{~m}$ and had three raised beds. Treatments were foliar applications of sulfur and fungal proteins (NBT Co. Ltd., Sevilla, Spain).

Each year in the last week of October, strawberries were planted. Plants were grown in an intensive annual system on drip-irrigated raised beds $(30 \mathrm{~cm}$ high and $50 \mathrm{~cm}$ wide) with black plastic mulch. Plants were spaced $25 \mathrm{~cm}$ apart within each of two rows per plot per raised bed, and the rows were spaced $25 \mathrm{~cm}$ apart. Beds were covered with small, polyethylene tunnels (microtunnels) from late November to early March for both seasons (17).

Concentrations of airborne conidia were studied with a 7-day volumetric spore sampler (Burkard Mfg. Co. Ltd., Ricksmanworth, Hertfordshire, England) located at the center of the field between two micro- tunnels and operated at a constant flow rate of 10 liters of air per min. The sampling orifice was $40 \mathrm{~cm}$ above the beds. Melinex tape coated with petroleum jelly was used in the spore sampler. The tape was replaced weekly and cut into 48-mm long segments, each representing a single day. Each tape segment was mounted on a glass slide with glycerin jelly $(50 \mathrm{ml}$ of glycerin, $7 \mathrm{~g}$ of jelly, $1 \mathrm{~g}$ of phenol, and $42 \mathrm{ml}$ of distilled water) and stained with acid fuch$\sin (5 \mathrm{ml}$ of glycerin jelly solution plus 0.5 $\mathrm{ml}$ of acid fuchsin) (7).

Each tape segment was examined at 2$\mathrm{mm}$ intervals in two longitudinal transects to the direction of tape movement with a light microscope $(\times 400)$. Counts were corrected to compensate for the area sampled and recorded as the number of conidia per cubic meter of air sampled per day (19). Distribution of conidia was calculated as the mean number of conidia recorded each hour of the day during the whole season. A weekly average of conidia was calculated and compared with weekly data for disease incidence.

With the help of an airborne spore and pollen atlas (9), S. macularis conidia were identified by their morphological characteristics: size ( 20 to $23 \times 13$ to $20 \mu \mathrm{m}$ ), barrel shape when turgid, and presence of granules inside the conidia (2).

Meteorological data were obtained from an automatic weather station (CR10X data logger, Campbell Scientific Ltd., Leicestershire, U.K.; Humidity and Temperature Sensor HMP 45C, Vaisala Oyj, Helsinki, Finland; and Tipping Bucket rain gauge ARG100, Campbell Scientific Ltd.). The weather station, part of the Meteorological Data Service Network (Junta de Andalucía), was located $5 \mathrm{~km}$ from the experimental plot. Hourly temperature and relative humidity data were used to calculate daily mean temperature (T) and daily mean relative humidity $(\mathrm{RH})$. Total daily rainfall (R) was also measured. The correlation between meteorological factors and conidial concentration was examined with Spearman's Correlation Test (Statistix 7; Analytical Software Ltd., La Jolla, CA), which is a general test used for microorganism infection data (6).

All ripe fruits were collected once a week in untreated subplots. Incidence of powdery mildew was expressed as the mean percentage of symptomatic fruit $(10,11)$. Since the effect of the cultivar on disease incidence was not significant, the 

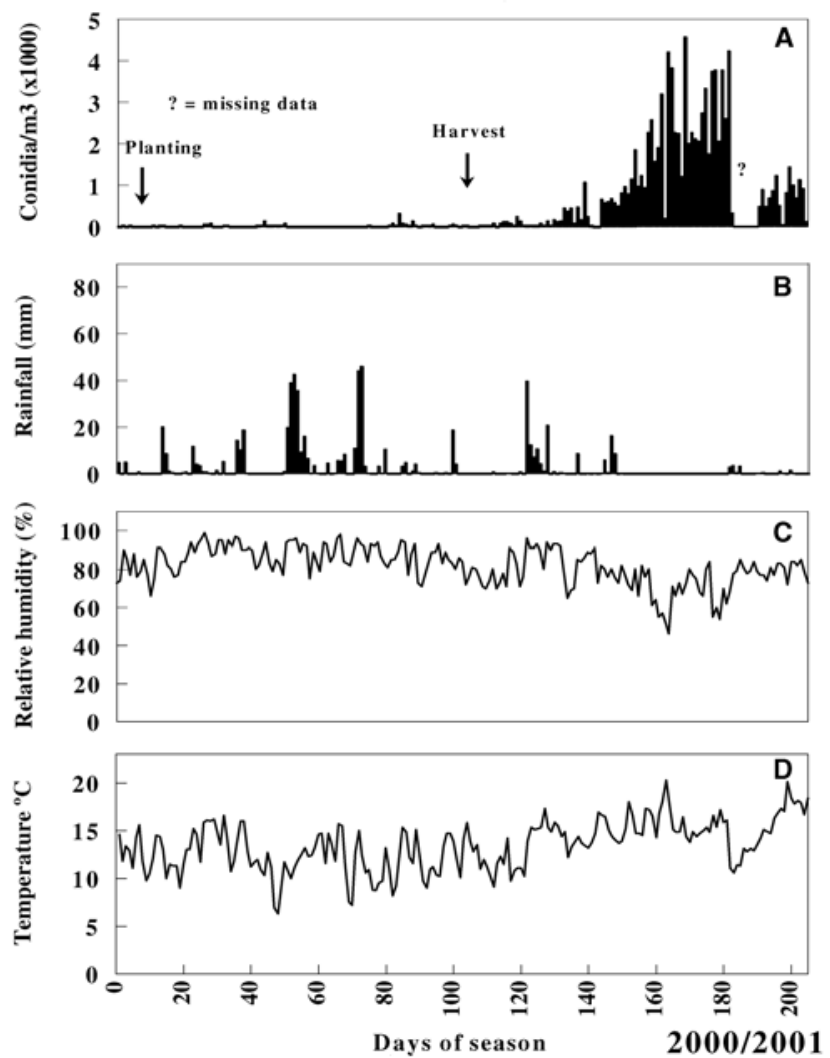

Fig. 1. A, Daily total airborne conidia of Sphaerotheca macularis; B, rainfall; $\mathbf{C}$, mean daily relative humidity; and $\mathbf{D}$, mean air temperature at the Moguer experimental plot during the 2000-2001 season. Concentrations of airborne conidia were determined with a Burkard volumetric spore sampler operated continuously. Arrows indicate dates of planting and initiation of harvest.
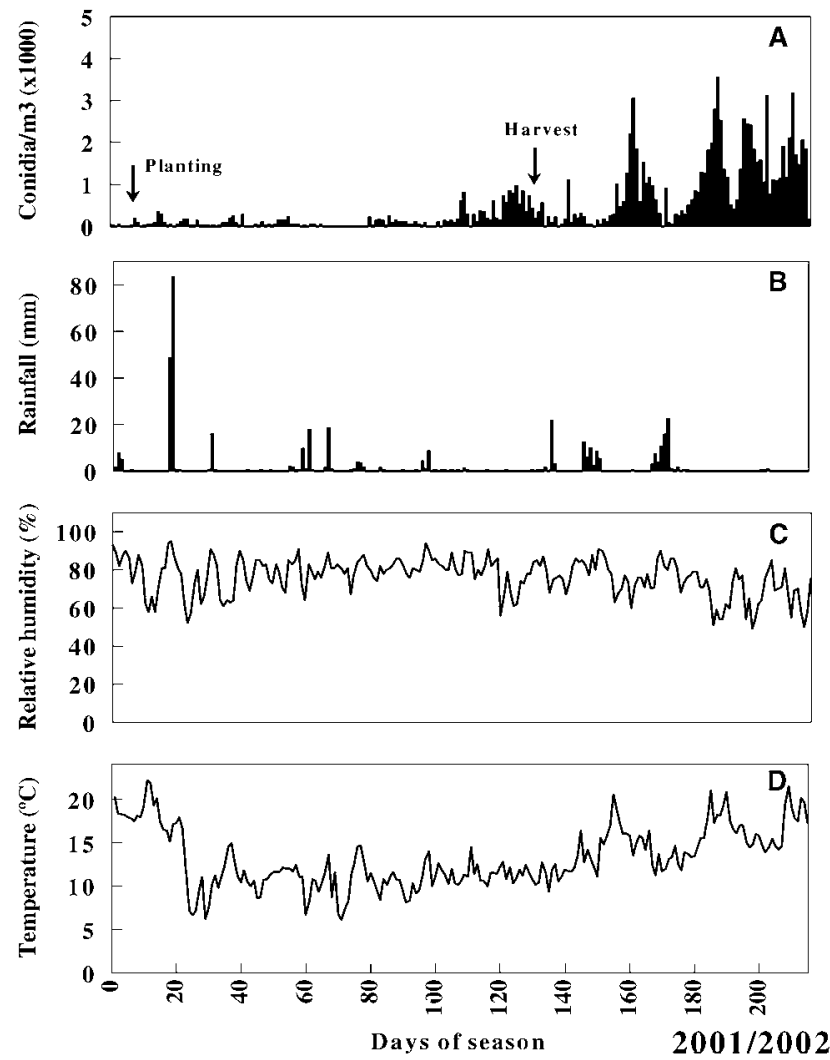

Fig. 2. A, Daily total airborne conidia of Sphaerotheca macularis; B, rainfall; $\mathbf{C}$, mean relative humidity; and $\mathbf{D}$, mean air temperature at the Moguer experimental plot during 2001-2002 season. Concentrations of airborne conidia were determined with a Burkard volumetric spore sampler operated continuously. Arrows indicate dates of planting and initiation of harvest. mean was calculated for the two cultivars. The correlation between disease incidence and weekly mean conidial concentration was examined using Spearman's Correlation Test. Conidial data were not transformed because the distribution was not normal (6).

\section{RESULTS}

Seasonal periodicity and influence of meteorological factors. In both years, conidia were first detected early in October, were collected throughout the season, and their numbers increased as the crop matured (Figs. 1 and 2).

During the 2000-2001 season, the concentration of conidia in sampled air ranged from 0 to 336 conidia $/ \mathrm{m}^{3}$ until the first day of harvest (day 107). During the harvest period (day 107 to day 205), the concentration of conidia ranged from 0 to 4,587 conidia $/ \mathrm{m}^{3}$ (Fig. 1A). Minimal concentration of conidia (zero) was recorded in 78 nonconsecutive days during the season. For these days, average $\mathrm{T}$ was $12.5^{\circ} \mathrm{C}$ (Fig. $1 \mathrm{~A}$ and $\mathrm{D}$ ), average $\mathrm{RH}$ was $86.4 \%$ (Fig. $1 \mathrm{~A}$ and $\mathrm{C}$ ) and rainfall was $>5 \mathrm{~mm}$ for $25.3 \%$ of these days (Fig. 1A and B). The highest concentration of conidia $(4,587$ conidia $/ \mathrm{m}^{3}$ ) was reached with a $\mathrm{T}$ of $14.4^{\circ} \mathrm{C}, 73 \% \mathrm{RH}$, and no rainfall (Fig. 1). Conidial concentration over 2,000 co-

Table 1. Spearman's rank correlation between number of conidia trapped in the air and meteorological factors and the weekly mean conidia concentration in the air and weekly mean disease incidence on the untreated subplots during the 2000-2001 and the 2001-2002 season in an experimental plot in Moguer (Huelva District, southwestern Spain)a

\begin{tabular}{lcccc}
\hline Season & Temperature & RH & Rainfall & $\begin{array}{c}\text { Disease incidence } \\
\text { (\% symptomatic fruit) }\end{array}$ \\
\hline $2000-2001$ & $0.48 * * *$ & $-0.49 * * *$ & $-0.28 * * *$ & $0.73 * *$ \\
$2001-2002$ & $0.40 * * *$ & $-0.44 * * *$ & $-0.31 * * *$ & $0.64 *$ \\
\hline
\end{tabular}

a $*=$ significant at $P=0.05, * *=$ significant at $P=0.01$, and $* * *=$ significant at $P=0.001$.

nidia $/ \mathrm{m}^{3}$ was registered on 20 nonconsecutive days (Fig. 1A). During this period, average $\mathrm{T}$ was $15.4^{\circ} \mathrm{C}$ (Fig. 1D), average RH was 67\% (Fig. 1C), and no rainfall occurred (Fig.1B).

During the 2001-2002 season, the concentration of conidia in sampled air ranged from 0 to 725 conidia/ $/ \mathrm{m}^{3}$ until the first day of harvest (day 129) and varied between 0 and 3,056 conidia $/ \mathrm{m}^{3}$ during the harvest period (day 129 to day 224) (Fig. 2A). No conidia were trapped on 37 nonconsecutive days during the season. For these days, average $\mathrm{T}$ was $12.0^{\circ} \mathrm{C}$ (Fig. $2 \mathrm{~A}$ and $\mathrm{D}$ ), average $\mathrm{RH}$ was $82.1 \%$ (Fig. 2A and $\mathrm{C}$ ), and rainfall was $>5 \mathrm{~mm}$ during $18.4 \%$ of the days (Fig. 2A and B). The highest concentration of conidia $\left(3,056\right.$ conidia $\left./ \mathrm{m}^{3}\right)$ was reached with a $\mathrm{T}$ of $18.0^{\circ} \mathrm{C}, 54 \% \mathrm{RH}$, and no rainfall (Fig. 2). Conidial concentration $>2,000$ conidia $/ \mathrm{m}^{3}$ was regis- tered for nine nonconsecutive days (Fig. 2A). During this period, average $\mathrm{T}$ was $16.2^{\circ} \mathrm{C}$ (Fig. 2D), average $\mathrm{RH}$ was $61.7 \%$ (Fig. 2C), and rainfall $<5 \mathrm{~mm}$ was registered on only 2 days (Fig. 2B).

The concentration of conidia over the crop was higher during the second season (2001-2002) than during the first (20002001) (Figs. 1A and 2A).

There was a significant and positive correlation between temperature and number of conidia trapped. The correlations between rainfall and conidia and $\mathrm{RH}$ and conidia were negative and significant (Table 1).

Diurnal periodicity. The number of airborne conidia trapped generally followed a diurnal pattern (Fig. 3). Conidia concentration was greatest between 1100 and $1900 \mathrm{~h}$ during the 2000-2001 season, with a peak between 1300 and 1500 h. During 


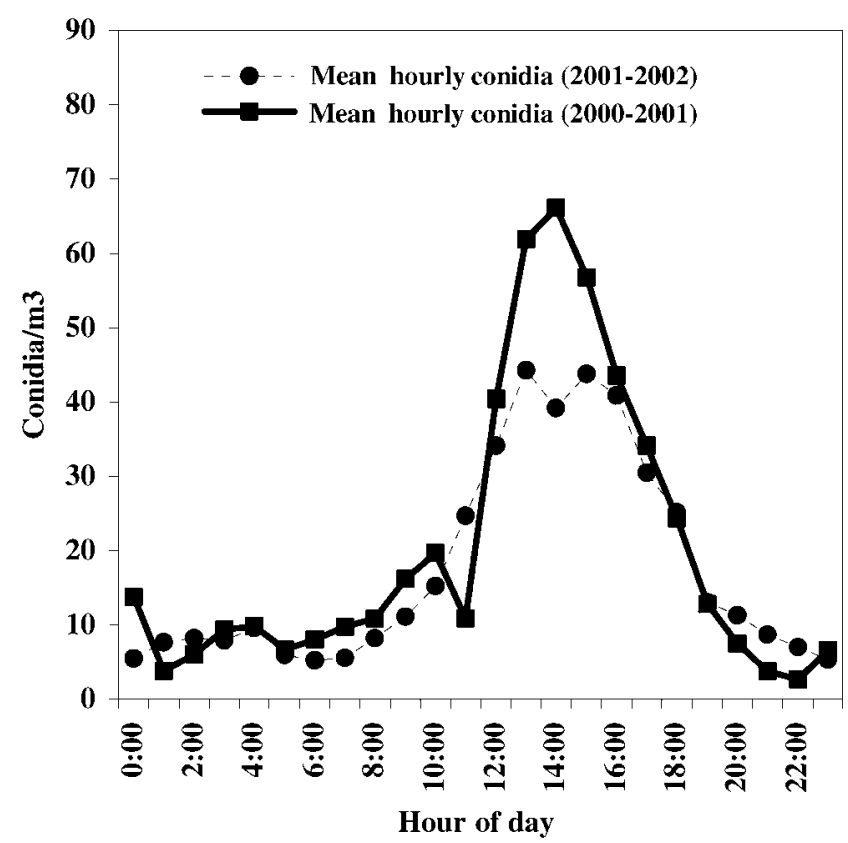

Fig. 3. Diurnal periodicity of Sphaerotheca macularis airborne conidia trapped from the air over a strawberry experimental plot in Moguer, Spain. Values given are the average of conidia trapped at the same hour of the day during the season 2000-2001 and 2001-2002. Concentrations of airborne conidia were determined with a Burkard volumetric spore sampler that was operated continuously.
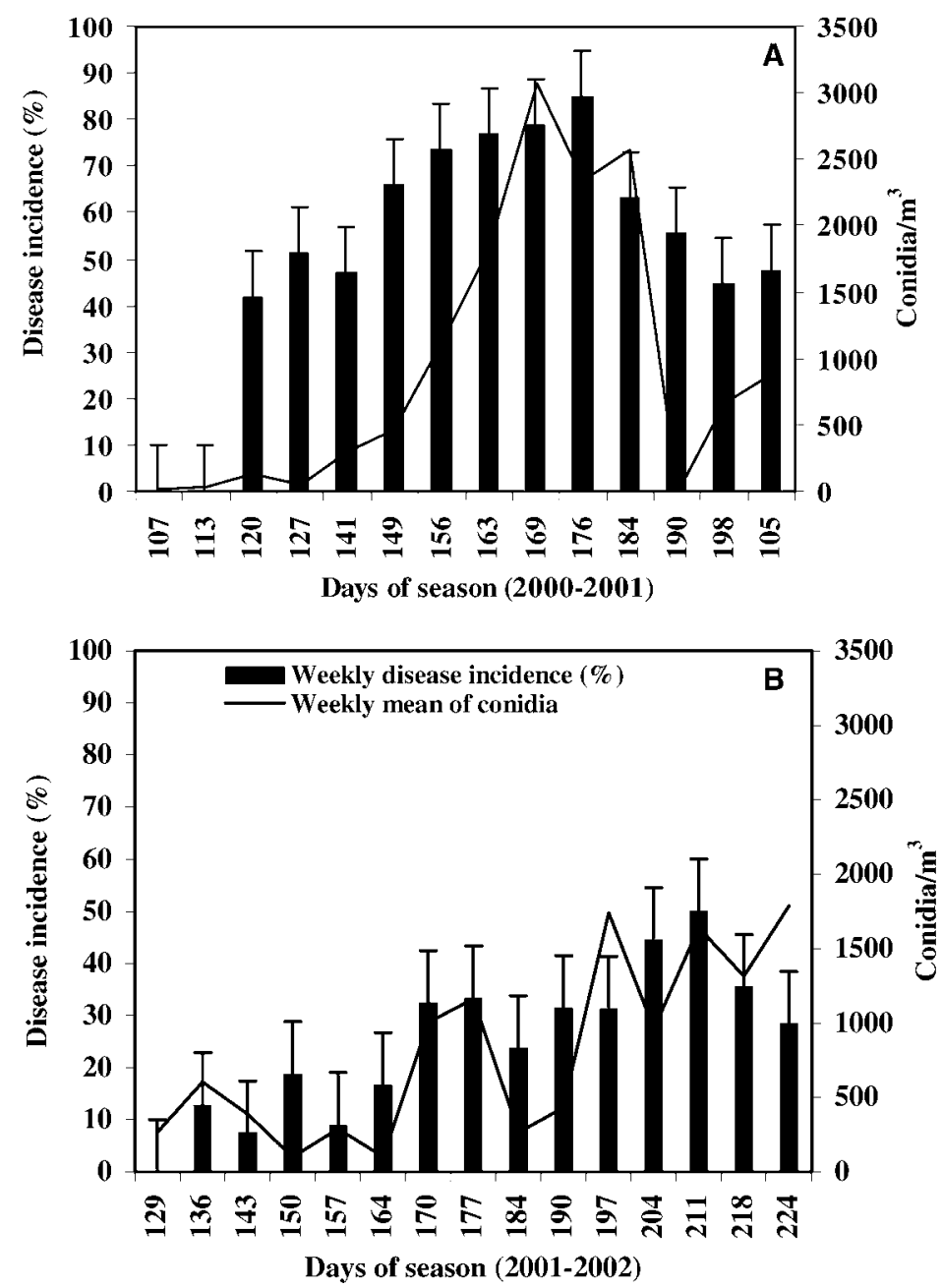

Fig. 4. Weekly incidence of powdery mildew on strawberry fruit in an experimental plot in Moguer, Spain during the A, 2000-2001 and B, 2001-2002 seasons. Disease incidence was estimated as the mean percentage of affected fruit harvested from untreated subplots. The number of conidia of Sphaerotheca macularis in the air is shown as weekly mean. Conidia were trapped in the plot by a Burkard volumetric spore sampler that was operated continuously. the second season, most conidia were trapped between 0900 and $2000 \mathrm{~h}$, with the peak between 1300 and $1500 \mathrm{~h}$.

Disease incidence. During the first season, the incidence of powdery mildew on fruit varied depending on the number of conidia trapped during the previous week. Thus, an increase in the number of conidia trapped led to a higher disease incidence 1 week later. Disease incidence was high from days 120 to 149 without corresponding high conidia concentration (Fig. $4 \mathrm{~A})$. During this period, rainfall was $>5$ $\mathrm{mm}$, whereas $\mathrm{T}$ was higher than $15^{\circ} \mathrm{C}$ and RH was over $90 \%$ (Fig. 1B, C, and D). During the first 2 months of the harvest period in the second season, this pattern was not so clearly observed, but for the rest of the season, the pattern was similar to that observed during the first season (Fig. 4B). In the second season, powdery mildew incidence and number of conidia trapped weekly were lower than those measured for the first season (Fig. 4). The correlation between disease incidence and number of conidia was positive and significant (Table 1).

\section{DISCUSSION}

After the planting date, the number of conidia trapped over the crop increased, indicating that the plants may have been an important source of inoculum. As Duhart et al. (8) reported in research carried out in nurseries, as much as $22 \%$ of plants exported to production fields were infected with $S$. macularis. When the harvest season started, the number of conidia trapped increased.

Rainfall decreased the concentration of conidia on the sampled air over the crop. Raindrops apparently washed conidia from the air, and may also have inhibited the sporulation of colonies on the leaf surface (20,26).

Optimal temperatures reported for powdery mildew vary depending on the crop and conditions where it is grown (12). For $S$. macularis on strawberry, optimal temperature range for germination is approximately 15 to $25^{\circ} \mathrm{C}$ (24). In our study, the period of peak conidia concentration corresponded with periods of $\mathrm{T}$ approximately $15^{\circ} \mathrm{C}$.

A negative correlation was found between $\mathrm{RH}$ and the conidia trapped. Although $S$. macularis needs high $\mathrm{RH}$ for germination of conidia and $\mathrm{RH}$ fluctuations for liberation of conidia $(2,15)$, free water on the leaf surface could inhibit the growth of the mycelium and the formation and germination of conidia (14).

As with the majority of the Erysiphales, the conidial maturation process is a photosensitive process. Therefore, conidia produced at night remain immature until they are exposed to daylight and then are released once maturation is completed (3).

Positive correlations between conidial presence and disease incidence indicates 
that the presence of higher conidia levels leads to a higher incidence of the disease if weather conditions permit the establishment of the pathogen on susceptible tissue. When one of the three meteorological factors measured was suboptimal for conidia germination and mycelium development, disease incidence decreased. Nevertheless, when meteorological conditions were highly favorable for disease development, disease incidence was high without high conidia concentration, as was observed during the first season (days 120 to 149). During this period, T and RH were optimal for disease development (12), but rainfall probably caused a reduction of conidia trapped $(20,26)$. Thus, meteorological factors could be considered responsible for the increase in the number of conidia trapped during the harvest period, and consequently for the increase of powdery mildew incidence.

For the management of powdery mildew, predictive models have been developed in other crops. Chellemi and Marois (4) developed a model for grape powdery mildew based on the estimation of inoculum germination rates and weather parameters. Sall (22) used the infection rate, the portion of infected tissue, and the length of the infection. For apple powdery mildew, $\mathrm{Xu}$ (25) developed three submodels to describe the influence of weather on conidial production, dispersion, and germination. Other researchers have considered the presence of airborne conidia over the crop on their model construction. Jeger (13) used cumulative spore catches and atmospheric conditions to predict disease incidence for apple powdery mildew, and Smith and Davies (23) worked out an empirical model for barley powdery mildew as a function of temperature and conidia trapped. The current work, carried out over a strawberry crop, could be the basis for development of a predictive model of powdery mildew occurrence in strawberry production, which would be a tool to improve crop management and the efficiency of fungicide applications.

\section{LITERATURE CITED}

1. Anonymous. 2003. Anuario Estadístico Agrario, ed. Junta de Andalucía.

2. Braun, U., ed. 1995. The Powdery Mildews (Erysiphales) of Europe. Gustav Fischer.

3. Byrne, J. M., Hausbeck, M. K., and Shaw, B. D. 2000. Factors affecting concentrations of airborne conidia of Oidium sp. among poinsettias in a greenhouse. Plant Dis. 84:10891095.

4. Chellemi, D. O., and Marois, J. J. 1999. Development of a demographic growth model for Uncinula necator by using a microcomputer spreadsheet program. Phytopathology 81:250254.

5. de los Santos, B., Blanco, C., Porras, M., Barrau, C., and Romero, F. 2002. First confirmation of Sphaerotheca macularis on strawberry plants in southwestern Spain. Plant Dis. 86:1049.

6. Díaz, M. R., Iglesias, I., and Jato, M. V. 1997. Airborne concentrations of Botrytis, Uncinula and Plasmopara spores in a vineyard in LeiroOurense (N.W. Spain). Aerobiologia 13:31-35.

7. Domínguez-Vilches, E., Galán-Soldevilla, C., Villamandos de la Torre, F., and InfanteGarcía-Pantaleón, F. 1992. Manejo y evaluación de los datos obtenidos en los muestreos aerobiológicos. Unidad de Monitorizaje Aerobiológico de la Universidad de Córdoba. Monografías REA./ENA. No. 1.

8. Duhart, M. E., Montes, F., Páez, J. I., and Vega, J. M. 1999. El Oidio de la Fresa en Huelva. Phytoma España 109:28-38.

9. Grant-Smith, E. 1986. Sampling and Identifying Allergenic Pollens and Molds. An Illustrated Identification Manual for Air Samplers. Vol. II. Blewstone Press, San Antonio, TX.

10. Hancock, J. F. 1999. Strawberries. CABI Publishing. Wallingford, UK.

11. Howard, C. M., and Albregts, E. E. 1982. Cleistothecia of Sphaerotheca macularis on strawberry plants. Plant Dis. 66:261-262.

12. Jarvis. W. R., Gubler, W. D., and Grove, G. G. 2002. Epidemiology of Powdery Mildews in Agricultural Pathosystems. Pages 169-199 in: The Powdery Mildews. R. R. Bélanger, W. R. Bushnell, A. J. Dik, and T. L. W. Carver, eds.
The American Phytopathogical Society, St. Paul, MN.

13. Jeger, M. J. 1984. Relating disease progress to cumulative number of trapped spores: Apple powdery mildew and scab epidemics in sprayed and unsprayed orchard plots. Plant Pathol. 33:517-523.

14. Jhooty, J. S., and McKeen, W. E. 1964. Studies on powdery mildew of strawberry caused by Sphaerotheca macularis. Phytopathology 55:281-285.

15. Lacey, J. 1996. Spore dispersal-Its role in ecology and disease: The British contribution to fungal aerobiology. Mycol. Res. 100:641660.

16. Legard, D., and Chandler, C. K. 2000. Evaluation of fungicides to control powdery mildew of strawberry, 1998. Fungic. Nematic. Tests. 55:128.

17. López-Aranda, J. M., and Bartual, R. 1999. Strawberry production in Spain. Cost Action 836: Working Group 2 and Management Committee Meetings. Málaga, Spain.

18. Maas, J. L. 1994. Compendium of Strawberry Diseases. The American Phytopathological Society, St. Paul, MN

19. Mediavilla-Molina, A., Angulo-Romero, J., Infante-García-Pantaleón, F., and DomínguezVilches, E. 1997. Influence of meteorological factors on the incidence of Cladosporium Link ex Fr. conidia in the atmosphere of Cordoba (Spain). Pages 117-126 in: Phenology in Seasonal Climates, I. H. Lieth and M. D. Schwartz, eds. Backhuys Publishers, Leiden, The Netherlands.

20. Paulus, A. O. 1990. Fungal diseases of strawberry. Hortic Sci. 25:885-889.

21. Peries, O. S. 1962. Studies on strawberry mildew caused by Sphaerotheca macularis (Wall. ex Fries) Jaczewski. I. Biology of the fungus. Ann. Appl. Biol. 50:211-224.

22. Sall, M. A. 1980. Epidemiology of grape powdery mildew: A model. Phytopathology 70:338-342.

23. Smith, L. P., and Davies, R. R. 1973. Weather conditions and spore trap catches of barley mildew. Plant Pathol. 22:1-10.

24. Spencer, D. M. 1978. The Powdery Mildews. Academic Press, London.

25. Xu, X. M. 1999. Modeling and forecasting epidemics on apple powdery mildew (Podosphaera leucotricha). Plant Pathol. 48:462-471.

26. Yarwood, C. E. 1936. The diurnal cycle of the powdery mildew Erysiphe polygoni. J. Agric. Res. 52:645-657. 